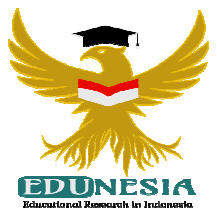

\title{
Efektivitas Pembelajaran Matematika Dengan Pendekatan Savi Dan Pendekatan Mekanistik Pada Materi Kubus Dan Balok Terhadap Prestasi Belajar Siswa Kelas VIII SMP
}

\author{
Fitri Juwina'; Yuli Amalia ${ }^{2}$ \\ 1,2Pendidikan Matematika, STKIP Bina Bangsa Meulaboh, Indonesia \\ ${ }^{2}$ Corresponding Email:amalia.y@yahoo.com, Phone Number : 0823 xxxx xxxx
}

\section{Article History:}

Received: Des 25, 2019

Revised: Jan 10, 2020

Accepted: Jan 24, 2020

Published: Jan 30, 2020

\section{Keywords:}

Leaning Achievement, Mecanistic,

SAVI,

\section{Kata Kunci:}

Mekanistik,

SAVI,

Prestasi Belajar

\section{How to cite:}

Juwina. F., \& Amalia, Y. (2020).

Efektivitas

Pembelajaran Matematika

Dengan Pendekatan Savi

Dan Pendekatan

Mekanistik Pada Materi

Kubus Dan Balok Terhadap

Prestasi Belajar Siswa Kelas

VIII SMP. Edunesia : Jurnal

Ilmiah Pendidikan, 1 (1): 40 45

\begin{abstract}
The purpose of this study was to determine whether learning mathematics with the SAVI approach is more effective than the mechanistic approach to the cube and beam material on the learning achievement of students of class VIII of SMP Negeri 1 Meulaboh. The approach in this research is a quantitative approach while the type of research is experimental research. The population in this study were all students of class VIII of SMP Negeri 1 Meulaboh and the sample was all students of class VIII A as an experimental class given learning by using the SAVI approach and all students from class VIII B as a control class given learning by using a mechanistic approach. Samples from this study were taken with a purposive sample technique. The research instrument provided was in the form of an initial test (pretest) and a final test (posttest). The data analysis technique used is the t-test analysis. The results of this study indicate that the mathematics learning achievement scores of students after being treated are higher than before being treated using the SAVI approach and the mechanistic approach. However, the results of the study also showed that the $t$ test conducted on the results of the initial test and the final test showed a significant difference in results between students using the SAVI learning approach and those using the mechanistic learning approach. because $=1.68$ or $=6.42$.
\end{abstract}

Abstrak: Tujuan dari penelitian ini adalah untuk mengetahui apakah pembelajaran matematika dengan pendekatan SAVI lebih efektif dari pada pendekatan mekanistik pada materi kubus dan balok terhadap prestasi belajar siswa kelas VIII SMP Negeri 1 Meulaboh. Pendekatan dalam penelitian ini adalah pendekatan kuantitatif sedangkan jenis penelitian adalah penelitian eksperimen. Populasi dalam penelitian ini adalah seluruh siswa kelas VIII SMP Negeri 1 Meulaboh dan sampelnya adalah seluruh siswa dari kelas VIII A sebagai kelas eksperimen yang diberikan pembelajaran dengan menggunakan pendekatan SAVI dan seluruh siswa dari kelas VIII B sebagai kelas kontrol yang diberikan pembelajaran dengan menggunakan pendekatan mekanistik. Sampel dari penelitian ini di ambil dengan teknik purposive sample. Instrument penelitian yang diberikan berupa tes awal (pretest) dan tes akhir (posttest). Teknik analisis data yang digunakan adalah analisis Uji-t. Hasil dari penelitian ini dengan $\alpha=0,05$ menunjukkan bahwa skor prestasi belajar matematika siswa sesudah diberikan perlakuan lebih tinggi dari pada sebelum diberikan perlakuan dengan menggunakan pendekatan SAVI dan pendekatan mekanistik. Akan tetapi hasil penelitian juga menunjukkan bahwa Uji-t yang dilakukan terhadap hasil tes awal dan tes akhir menunjukkan adanya perbedaan hasil yang cukup signifikan antara siswa yang menggunakan pendekatan pembelajaran SAVI dengan yang menggunakan pendekatan pembelajaran mekanistik. karena $t_{\text {hitung }}=6,42>t_{\text {tabel }}=1,68$ atau $t_{\text {tabel }}=1,68<t_{\text {hitung }}=6,42$. 


\section{A. Pendahuluan}

Matematika merupakan salah satu bidang studi yang dipelajari pada setiap jenjang sekolah baik tingkat dasar, menengah, maupun perguruan tinggi. Berdasarkan hasil observasi peneliti juga diperoleh data bahwa hasil ulangan siswa dalam bidang matematika menunjukkan dari 21 siswa masih banyak siswa yang harus mengikuti remedial karena hasil belajar siswa tidak tuntas, masih kurang memuaskan dengan nilai rata-rata dibawah Kriteria Ketuntasan Minimal (KKM). yang ditetapkan di sekolah tersebut yaitu 65 sehingga masih perlu ditingkatkan. Hal ini tentu menjadi kendala yang harus di antisipasi penyebabnya agar proses belajar mengajar berjalan lancar.

Peranan guru menjadi salah satu faktor yang dapat menyelesaikan masalah ini. Pentingnya peranan guru dalam proses pembelajaran (Harmalik, 2001) yaitu "Guru merupakan salah satu faktor yang menentukan keberhasilan proses pendidikan". Dengan demikian guru hendaknya berwawasan luas dan mampu mengantisipasi persoalanpersoalan yang terjadi dalam proses belajar mengajar. Guru merupakan salah satu komponen yang memiliki kesempatan untuk bertatap muka lebih banyak dengan siswa dibandingkan dengan komponen lainnya. Oleh karena itu, tanggung jawab guru dalam perbaikan proses pembelajaran sangat diperlukan. Diharapkan dengan adanya perbaikan pembelajaran tersebut kualitas pembelajaran yang dilakukan dapat meningkat.

Terkait dengan pentingnya peranan guru, maka untuk meningkatkan ketuntasan belajar siswa guru harus tepat dalam memilih pendekatan pembelajaran. Pendekatan pembelajaran yang digunakan harus mampu membangkitkan minat belajar siswa. Pembelajaran secara mekanistik sekarang ini sudah tidak cocok lagi karena didalam metode ini, guru hanya mentransfer ilmu kepada anak didik dan sejak dulu metode ini telah dipergunakan sebagai alat komunikasi lisan antara guru dan siswa dalam interaksi edukatif. Metode ini lebih banyak menuntut keaktifan guru dari pada siswa. Penggunaan metode pembelajaran yang mononton (mekanistik), dimungkinkan siswa akan mengantuk dan perhatiannya kurang karena membosankan.

Model pembelajaran harus bisa mengubah gaya belajar siswa dari siswa yang belajar pasif menjadi aktif dalam mengkonstruksikan konsep. Model pembelajaran yang tepat membuat matematika lebih berarti, masuk akal, menantang, menyenangkan dan cocok untuk siswa. Gambaran permasalahan-permasalahan di atas perlu diperbaiki guna meningkatkan motivasi, perhatian, pemahaman dan prestasi belajar siswa. Oleh karena itu guru mampu menawarkan metode dalam mengajar yang lebih efektif yang dapat membangkitkan perhatian siswa sehingga siswa menjadi aktif dan termotivasi untuk belajar, serta harus diimbangi dengan kemampuan guru dalam menguasai metode tersebut. Salah satunya adalah melalui pendekatan "SAVI" (Somatis, Auditori, Visual, Intelektual). Unsur-unsur pendekatan SAVI adalah :

1. Somatis(S) : Belajar dengan bergerak dan berbuat.

2. Auditori(A) : Belajar dengan berbicara dan mendengar.

3. $\operatorname{Visual}(\mathrm{V})$ : Belajar dengan mengamati dan menggambarkan .

4. Intelektual(I) : Belajar dengan memecahkan masalah dan merenung.

Pembelajaran matematika dengan pendekatan SAVI bisa optimal jika keempat unsur SAVI ada dalam satu peristiwa pembelajaran matematika. Misalnya, siswa akan belajar sedikit tentang matematika dengan menyaksikan presentasi $(\mathrm{V})$, tetapi mereka dapat belajar lebih banyak jika mereka dapat melakukan sesuatu (S), membicarakan atau mendiskusikan apa yang mereka pelajari (A), serta memikirkan dan mengambil kesimpulan atau informasi yang mereka peroleh untuk diterapkan dalam menyelesaikan 
soal-soal (I). Atau siswa dapat meningkatkan kemampuan mereka dalam mengemukakan ide (I), jika mereka secara simultan menggerakan sesuatu (S) untuk menghasilkan piktogram, diagram, grafik dan lain sebagainya (V) sambil mendiskusikan atau membicarakan apa yang sedang mereka kerjakan (A) (Meier, 2002).

Berdasarkan pernyataan tersebut, maka perlu dilakukan penelitian lebih lanjut guna mengetahui seberapa besar efektivitas pembelajaran matematika dengan menggunakan pendekatan SAVI dan pendekatan Mekanistik terhadap prestasi belajar matematika siswa, adakah perbedaan efektivitas antara pembelajaran dengan menggunakan pendekatan SAVI dengan pendekatan Mekanistik berdasar prestasi belajar matematika siswa, serta manakah yang lebih efektif, pembelajaran matematika dengan menggunakan pendekatan SAVI ataukah pembelajaran dengan menggunakan pendekatan Mekanistik yang lebih efektif jika dilihat dari prestasi belajar matematika siswa. Untuk itu peneliti tertarik untuk menerapkan pendekatan SAVI dalam pembelajaran matematika di SMP Negeri 1 Meulaboh.

\section{B. Metode}

Penelitian ini menggunakan pendekatan kuantitatif. Ditinjau dari jenis penelitiannya maka penelitian ini merupakan penelitian pendidikan yang dilakukan dengan penelitian eksperimen. Menurut (Sulipan, 2003) "Penelitian eksperimen merupakan kegiatan penelitian yang bertujuan untuk menilai pengaruh suatu perlakuan atau tindakan penelitian terhadap tingkah laku siswa atau menguji hipotesis tentang ada tidaknya pengaruh tindakan itu bila di bandingkan dengan tindakan lain".

Tabel 1. Rancangan Penelitian

\begin{tabular}{cccc}
\hline Kelompok & $\begin{array}{c}\text { Pre- } \\
\text { test }\end{array}$ & Perlakuan & $\begin{array}{c}\text { Post- } \\
\text { test }\end{array}$ \\
\hline Eksperimen & $\mathrm{T}_{1}$ & $\mathrm{X}$ & $\mathrm{T}_{2}$ \\
\hline Kontrol & $\mathrm{T}_{1}$ & $\mathrm{Y}$ & $\mathrm{T}_{2}$ \\
\hline
\end{tabular}

Keterangan :

X : Pendekatan SAVI

Y : Pendekatan Mekanistik

$\mathrm{T}_{1} \quad$ : Pre-test

$\mathrm{T}_{2} \quad$ : Post-test

$\mathrm{T}_{1}=\mathrm{T}_{2}$

Berdasarkan desain penelitian di atas, kedua kelompok diberi tes awal (Pretest) dengan tes yang sama. Setelah diberi perlakuan yang berbeda, kedua kelompok di tes dengan tes yang sama sebagai akhir tes (Posttest). Hasil kedua tes terakhir dibandingkan (diuji perbedaannya), dengan demikian juga antara hasil tes awal dengan tes akhir pada masing-masing kelompok.

Tempat dilaksanakan penelitian ini adalah di SMP Negeri 1 Meulaboh yang terletak di Meulaboh di Jalan Teuku Umar Kecamatan Johan Pahlawan Kabupaten Aceh Barat. Waktu yang diperlukan untuk melakukan penelitian di lapangan yaitu dari Mei 2016. Perlakuan diberikan kepada siswa kelas VIII A dan VIII B pada semester genap tahun ajaran 2015/2016. 
Populasi adalah keseluruhan subjek penelitian Arikunto (2010). Adapun populasi dalam penelitian ini adalah siswa kelas VIII SMP Negeri 1 Meulaboh. Menurut (Arikunto, 2010) "Sampel adalah wakil populasi yang diteliti". Bila populasi terlebih besar tidak mungkin mempelajari semua yang ada pada populasi, maka dapat menggunakan sampel yang diambil dari populasi itu (Arikunto, 2002). Maka dalam penelitian ini, penulis mengambil sampel dengan cara purposive sample (Sampel bertujuan). Jadi diambil dua sampel yaitu kelas VIII-A dan kelas VIII-B dimana peneliti memiliki alasan bahwa siswasiswi kelas VIII-A dan kelas VIII-B mempunyai kebiasaan yang sama dalam mengikuti pembelajaran. Dengan demikian penulis mengambil sebuah keputusan dengan mengambil satu kelas dari dua kelas yang ada, yaitu kelas VIII-A sebagai kelas eksperimen dalam penelitian ini.

Selanjutnya kelas VIII-A disebut kelas eksperimen yaitu kelas yang dalam pembelajarannya ditetapkan pendekatan SAVI sedangkan kelas VIII-B disebut kelas kontrol yaitu kelas dalam pembelajarannya ditetapkan pendekatan mekanistik.

Pelaksanaan penelitian terdiri dari dua tahap, tahap persiapan dan tahap pelaksanaan. Kegiatan yang dilakukan pada tahap persiapan yaitu pembuatan kesepakatan dengan guru bidang studi matematika pada sekolah yang akan dijadikan tempat penelitian, penyusunan perangkap pembelajaran, penyusunan instrument penelitian dan mengkonsultasikan perangkap pembelajaran dan instrument penelitian kepada pembimbing dan guru bidang studi metematika. Selanjutnya pada tahap pelaksanaan sebelum dilaksanakan proses pembelajaran matematika dengan menggunakan pendekatan SAVI di kelas eksperimen dan pendekatan Mekanistik di kelas kontrol, siswa diberi pre-test untuk mengukur hasil belajar matematika siswa. Setelah pretest selesai, siswa diberi perlakuan yaitu kegiatan pembelajaran matematika sesuai dengan RPP yang telah disusun menggunakan pendekatan SAVI di kelas eksperimen dan pendekatan mekanistik di kelas kontrol. Detelah kegiatan pembelajaran selesai diberi Posttest untuk mengukur hasil belajar matematika siswa. Setelah semua proses dilaksanakan jawaban siswa dievaluasi sesuai dengan pendoman penskoran yang dipakai.

Dalam instrument penelitian terdapat beberapa lembar instrument yaitu lembar tes awal, lembar tes akhir dan RPP. Lembar Tes awal (Pretest) merupakan pertanyaan yang dilontarkan guru kepada peserta didiknya sebelum memulai pelajaran. Sedangka Lembar Tes akhir (Postest) merupakan pertanyaan yang diberikan setelah pelajaran materi disampaikan serta membandingkan hasil antara sebelum pembelajaran dengan setelah pembelajaran.

\section{Hasil dan Pembahasan}

Sebelum penelitian dilakukan, peneliti menyiapkan alat yang digunakan untuk penelitian yang disebut dengan instrumen penelitian. Instrumen tersebut terlebih dahulu harus divalidasikan oleh validator yang bertujuan agar instrumen layak untuk digunakan. Dalam penelitian ini yang menjadi validator adalah dosen Sekolah Tinggi Keguruan dan Ilmu Pendidikan (STKIP) Bina Bangsa Meulaboh.

Data yang peneliti kumpulkan dalam penelitian ini berasal dari tes awal dan tes akhir. Tes awal dilakukan untuk mendapatkan gambaran kemampuan awal siswa terhadap materi kubus dan balok. Distribusi angka-angka yang terdapat dalam tabel merupakan skor yang diperoleh siswa kelas eksperimen dan kelas kontrol pada tes kemampuan awal sebelum memulai pembelajaran dengan menggunakan pendekatan SAVI dan pendekatan Mekanistik dalam menyelesaikan materi kubus dan balok. Setelah 
skor tes terkumpul, selanjutnya dianalisis dengan menggunakan statistik uji-t. Uji-t dilakukan setelah data-data hasil penelitian di uji normalitas dan homogenitasnya. Homogenitas nilai dilakukan dengan cara terlebih dahulu menentukan varians kelas eksperimen dan varians kelas kontrol.

Hasil tes awal menunjukkan bahwa nilai tertinggi kelas eksperimen dengan kelas kontrol sama, yaitu kelas eksperimen 45 sedang kelas kontrol 45 begitu juga dengan nilai terendahnya, kelas eksperimen memiliki nilai terendah 32 sedang kelas kontrol 32 ini mengakibatkan tidak berbeda jauh pada rata-rata hasil pretes. Kelas eksperimen memiliki rata-rata 3,8 sedang kelas kontrol 37,71 ini menunjukkan bahwa tidak adanya perbedaan kemampuan antara kelas eksperimen dengan kelas kontrol namun kedua kelas masih memiliki variansi yang homogen ditunjukkan oleh hasil uji homogenitas varians diantara keduanya yang memberikan hasil bahwa kedua kelas adalah homogeny, sehingga kedua kelas masih memenuhi untuk dijadikan sebagai obyek penelitian.

Tes akhir didapatkan setelah perlakuan diberikan. Pada kelas eksperimen dilakukan dengan pembelajaran pendekatan SAVI sedangkan kelas kontrol dilakukan dengan pembelajaran pendekatan mekanistik. Hasil tes akhir menunjukkan bahwa nilai tertinggi dan terendah yang dicapai oleh siswa pada kelas eksperimen secara berturutturut adalah 88 dan 55 dengan rata-rata 75,33 sedangkan untuk kelas kontrol secara berturut-turut adalah 74 dan 55 dengan rata-rata 62,23.

Dilihat dari rata-rata hasil tes awal dan tes akhir masing-masing kelas didapatkan bahwa kelas eksperimen mengalami kenaikan yang cukup besar sedangkan kelas kontrol hanya sedikit. Uji-t yang dilakukan terhadap hasil tes awal dan tes akhir menunjukkan adanya perbedaan hasil yang cukup signifikan antara siswa yang menggunakan pendekatan pembelajaran SAVI dengan yang menggunakan pendekatan pembelajaran mekanistik.karena $t_{\text {httung }}=6,42>t_{\text {tabel }}=1,68$ atau $t_{\text {tabel }}=1,68<t_{\text {httung }}=6,42$. Sehingga $H_{0}$ ditolak. $H_{l}$ diterima karena $t_{\text {httung }}>t_{\text {tabel }}$. Maka dapat disimpulkan bahwa pembelajaran matematika dengan menggunakan pendekatan SAVI lebih efektif dari pada pembelajaran dengan menggunakan pendekatan mekanistik terhadap prestasi belajar siswa.

Proses pembelajaran dengan menggunakan pendekatan SAVI menjadikan siswa menjadi lebih mampu berpartisipasi dalam pembelajaran,siswa menjadi lebih aktif secara fisik, aktif dalam berkomunikasi dalam kelompok, siswa menjadi lebih tahu inti dari pembelajaran yang mereka lakukan dengan adanya kesimpulan, siswa menjadi lebih mampu dalam menyelesaikan masalah-masalah yang berkaitan dengan materi, serta kesan senang dalam pembelajaran lebih terlihat, sedang pembelajaran dengan menggunakan pendekatan mekanistik menjadikan peran guru sangatlah dominan didalam kelas, dan siswa menjadi kurang aktif, siswa hanya mengikuti kehendak guru baik apa yang ditulis maupun apa yang telah disampaikan guru, suasana kelas yang terkesan "sunyi" menjadi sangat dominan dalam kelas, meskipun dalam pelaksanaan pembelajaran siswa juga telah diberi waktu untuk aktif dalam bertanya, akan tetapi hasilnya pembelajaran tetaplah terkesan "sunyi".

\section{Kesimpulan}

Berdasarkan hasil penelitian dan pembahasan dari data yang diperoleh maka dapat disimpulkan bahwa dari hasil pengolahan data didapat $\boldsymbol{t}_{\text {hitumg }}=6,42$ dan $t_{\text {tabel }}=1,68$ sehingga $t_{\text {hitung }}>t_{\text {tabel }}$, hal ini berarti hipotesis $H_{i}$ dapat diterima. Bunyi 
hipotesis $H_{t}$ adalah pembelajaran matematika dengan menggunakan pendekatan SAVI dapat meningkatkan prestasi belajar siswa. Hal ini berarti pelaksanaan pembelajaran matematika dengan pendekatan SAVI lebih efektif dari pada pembelajaran dengan menggunakan pendekatan mekanistik terhadap prestasi belajar siswa

Dari hasil pengolahan data juga didapat nilai rata-rata tes akhir dari masingmasing kelas berbeda. Nilai rata-rata kelas eksperimen yaitu 75,33 dan nilai rata-rata kelas kontrol yaitu 62,23. Perbedaan nilai tersebutdisebabkankarena perbedaan perlakuan selama proses pembelajaran berlangsung. Jadi dapat disimpulkan pembelajaran dengan pendekatan SAVI efektif digunakan dalam pembelajaran matematika pada materi kubus dan balok terhadap prestasi belajar siswa.

\section{Daftar Pustaka}

Arikunto, S. (2002). Dasar-dasar Evaluasi Pendidikan.Jakarta:PT.Bumi Aksara. . (2010). Prosedur Penelitian Suatu Pendekatan Praktek. Jakarta: Rineke Cipta.

Hamalik, O. (2001). Proses Belajar Mengajar. Jakarta : Bumi Aksara.

Meier, D. (2002). Accelerated Learning Handbook. Bandung: Kaifa.

Nasution, S. 2010. Berbagai Pendekatan dalam Proses Belajar dan Mengajar. Jakarta: Bumi Aksara.

Sari, I.P. (2015). Perbandingan Hasil Belajar Matematika Siswa Melalui Pendekatan Contextual Teaching And Learning (CTL) Dengan Pendekatan Mekanistik Terhadap Hasil Belajar Siswa Pada Materi Lingkaran Di Kelas XI IPA 3 MAN Meulaboh-1 Kabupaten Aceh Barat. Skripsi, Aceh Barat : STKIP Bina Bangsa Meulaboh.

Slameto. (2010). Belajar dan Faktor-faktor yang Mempengaruhi.Jakarta : Rineka Cipta.

Syah, M. (2011). Psikologi Belajar. Jakarta: Rajawali Pers

Wina, S, (2011). Strategi Pembelajaran Berorintasi Standar Proses Pendidikan. Jakarta: Kencana 